\title{
Growth Performance of Some Multipurpose Tree Species Around the Homesteads in Gimbo District, Southwestern Ethiopia
}

\author{
Getahun Yakob Edo ${ }^{1, *}$, Kebede Gizachew Gebremedihn², Anteneh Fekadu Woldsenbet ${ }^{1}$, \\ Kefyalew Kassa Guta² \\ ${ }^{1}$ Southern Agricultural Research Institute (SARI), Natural Resource Research Directorate, Hawassa, Ethiopia \\ ${ }^{2}$ Bonga Agricultural Research Center, Bonga, Ethiopia
}

Email address:

getahunyakob@gmail.com (G. Y. Edo)

${ }^{*}$ Corresponding author

To cite this article:

Getahun Yakob Edo, Kebede Gizachew Gebremedihn, Anteneh Fekadu Woldsenbet, Kefyalew Kassa Guta. Growth Performance of Some Multipurpose Tree Species Around the Homesteads in Gimbo District, Southwestern Ethiopia. Agriculture, Forestry and Fisheries.

Vol. 6, No. 1, 2017, pp. 1-5. doi: 10.11648/j.aff.20170601.11

Received: September 11, 2016; Accepted: September 28, 2016; Published: January 12, 2017

\begin{abstract}
The objective of the study was to evaluate the performance of some exotic (Sesbania sesban, Leucaena leucocephala, Grevillea robusta, Azadirachta indica, and Casuarina equisetifolia) and indigenous (Cordia africana, Millettia ferruginea, Albizia gummifera, Moringa stenopetala and Prunus africanus) tree species at the backyard and boundary of homegardens in Gimbo district, South west Ethiopia. The seedlings were produced in a nursery, transplanted around the homesteads and have been studied for three years. The saplings were monitored for survival rates and growth performances by measuring root collar diameters and heights. There was significant difference in survival among the species investigated $(\mathrm{P}<0.05)$. Survival percent were varies from 24.8 to 86.5 across the species. The highest survival rate was recorded for $C$. africana and followed by G. robusta and $S$. sesban at the third year of experimentation. Significant differences in height growth $(\mathrm{P}<0.05)$ and diameter growth were also observed. Among tree species planted at the backyard of homegardens, $S$. sesban performed best in terms of mean height and root collar diameter followed by C. africana. M. ferruginea showed the lowest main height. Among tree species investigated at the boundary of homegardens, G. robusta showed the highest growth in height, followed by M. stenopetala. Mean root collar diameter was highest for M. stenopetala, followed by G. robusta. A. indica showed the lowest mean root collar diameter. It was concluded that promising exotic and indigenous tree species could be used for diversification of agroforestry home gardens.
\end{abstract}

Keywords: Agroforestry, Height Growth, Root Collar Diameter, Survival Rate, Boundary, Backyard

\section{Introduction}

Land degradation in Ethiopia is a major problem due to a number of factors. One of the important causes is the removal of forest and vegetative cover as a result of increased human population leading to high demand for forest products and land for expanding the agricultural activities [1, 2]. Consequently, these areas are now characterized by loss of soil fertility and soil erosion problems.

South Wes Ethiopia particularly, Kaffa zone is well known by high vegetation cover and most of the surrounding area is covered by tropical rain forest comprising a rich mixture of woody species arranged in many stories [3]. In spite of the importance of forest ecosystem to the livelihoods of the people in the area, the forest is dwindling from time to time due to high exploitation of woody and non-woody products. The integration of woody species in agricultural landscape could reduce the pressure on the surrounding natural forest. For instance, agroforestry, which combine forestry and agriculture, have the capacity to sustain the productivity of farmlands [4]. Moreover, the system could also serve as buffer zone for forest degradation and deforestation.

Homegardens are the most prominent cropping system in 
the south and southwestern part of Ethiopia [5]. In Gimbo district, farmers practice homegardens for economic, social and environmental benefits [6]. These traditional agroforestry practices could be intensified by using fast growing multipurpose tree species (MPTS) to satisfy the demands of the growing population.

Before introducing new trees and shrub species in any type of agroforestry system in the area, evaluation of compatible species is very critical. Deciding what species to plant in any agroforestry system to meet the intended objectives require a well- conducted field trial to match a species to a particular site $[7,8]$. The most reliable information is based on trial planting in the proposed agroforestry system [9]. The first trial should be a species screening trial that will test the survival and early growth of the species in one to three years [10].

Many experiments on growth performance of multipurpose trees and shrubs have been conducted in different parts of the country [11- 17] to meet the ever - increasing demand of forest products. However, the findings from these studies hardly hold true for South West Ethiopia, as the requirements for the survival and growth of species tend to vary across regions and among agro-ecology. In addition, the findings have given little attention for tree and shrub species that could be planted around the homesteads. Thus, this warrants further empirical investigation on growth performance and potential of the species for agroforestry homegardens in South West Ethiopia. This study could provide information for any intervention in agroforestry homegardens in the study area. The present study aims to assess the growth performance of tree species in terms of early growth characteristics such as survival, height and diameter to select the best-performing ones in agroforestry homegardens in South West Ethiopia.

\section{Materials and Methods}

\subsection{Study Site}

The study was conducted at Shomba Kichib site in Gimbo district which is found in Kafa Zone, $430 \mathrm{~km}$ south-west of Addis Ababa. It is situated between $07^{\circ} 00^{\prime}-7^{\circ} 25^{\prime} \mathrm{N}$ Latitude and $35^{\circ} 55^{\prime}-36^{\circ} 37^{\prime}$ E Longitude, and within the altitudinal range from 1600 to $1900 \mathrm{~m}$. The mean annual rainfall ranges from $1710 \mathrm{~mm}$ to $1892 \mathrm{~mm}$. The area is characterized by a long rainy season that extends from March through October. The mean maximum and minimum temperatures are $27.1^{\circ} \mathrm{C}$ and $11.8^{\circ} \mathrm{C}$, respectively. The soil of the area is characterized by a deep, dark reddish top layer overlying a dark red and dark reddish brown clay loams [18].

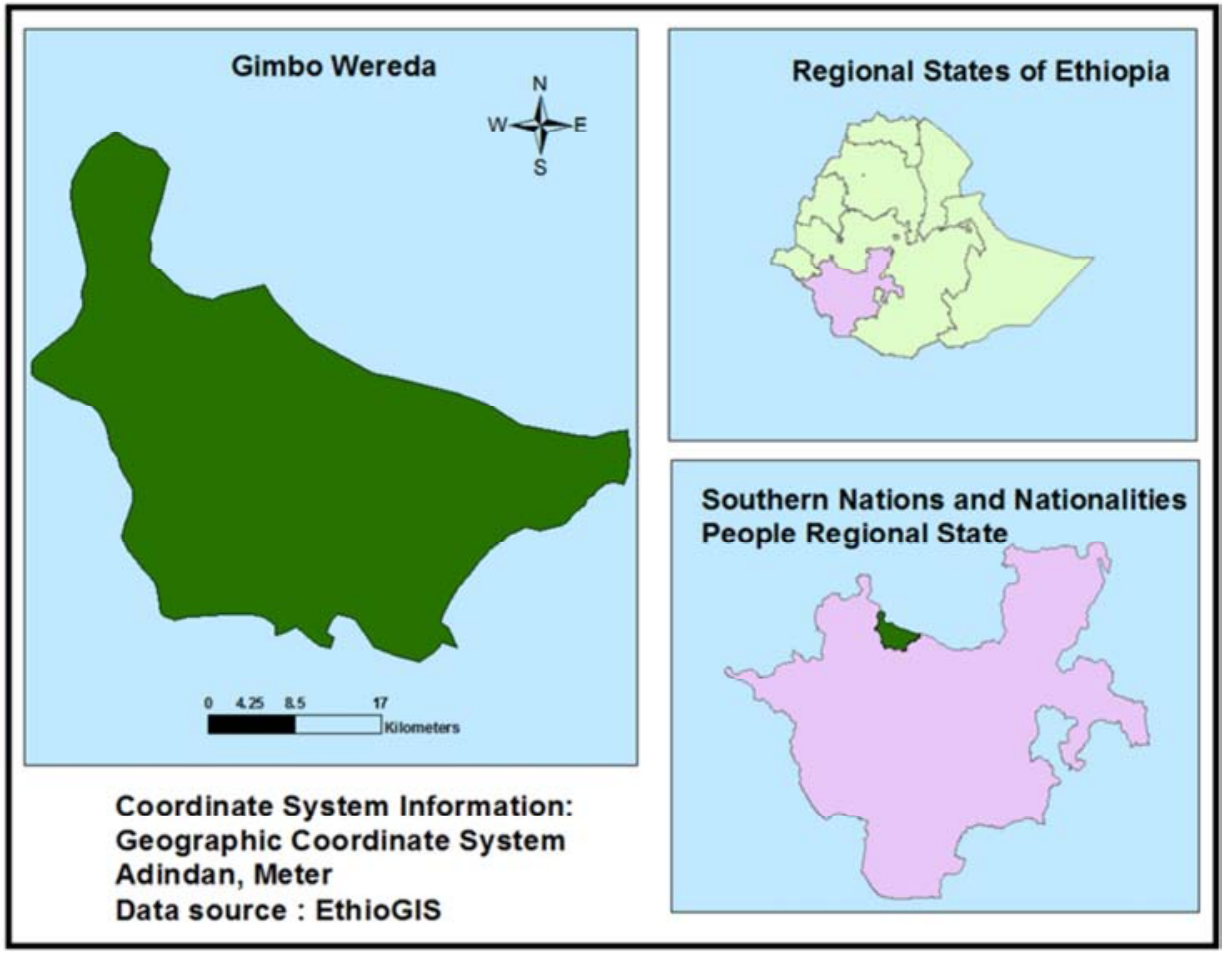

Figure 1. Map of the study area.

\subsection{Plant Material and Nursery Management}

Seeds of the multipurpose trees included in the trials (Table1) were obtained from National Forest Research Center. Seedlings for the trials were raised at Shomba Kichib nursery sites in Kaffa zone between Decembers - June 2004 close to the study sites. Nursery sowing of the multipurpose species was done on seedbeds and after germination the seedlings were pricked out into white polythene tubes. A bamboo shed was set up immediately after pricking out to provide shade and was removed as necessary. While in the nursery the seedlings were watered twice per day during the morning and evening except on days when it rained. This was, however, reduced to once every other day three weeks 
prior to planting. Weeds were removed on detection and rootpruning was done when ever roots out grew the polythene containers. No chemicals were applied to the seedlings in the nursery.

Table 1. List of MPTS included in the study, their planting niche and spacing.

\begin{tabular}{|c|c|c|c|}
\hline Species Name & Family & $\begin{array}{l}\text { Planting } \\
\text { Niche }\end{array}$ & $\begin{array}{l}\text { Spacing } \\
(\mathrm{m})\end{array}$ \\
\hline Cordia africana Lam. & Boraginaceae & Backyard & $4 * 4$ \\
\hline $\begin{array}{l}\text { Millettia ferruginea } \\
\text { (Hochst.) Bak. }\end{array}$ & Fabaceae & Backyard & $4 * 4$ \\
\hline $\begin{array}{l}\text { Sesbania sesban (L.) } \\
\text { Merr. }\end{array}$ & Papilionoideae & Backyard & $4 * 4$ \\
\hline $\begin{array}{l}\text { Albizia gummifera } \\
\text { (J.F.Gmel.) C.A.Sm. }\end{array}$ & Fabaceae & Backyard & $4 * 4$ \\
\hline $\begin{array}{l}\text { Leucaena leucocephala } \\
\text { (Lam.) De Wit. }\end{array}$ & Mimosoideae & Backyard & $4 * 4$ \\
\hline Grevillea robusta $\mathrm{R} . \mathrm{Br}$. & Proteaceae & Boundary & $2 * 2$ \\
\hline $\begin{array}{l}\text { Moringa stenopetala } \\
\text { (Bak.J) Cuf. }\end{array}$ & Moringaceae & Boundary & $2 * 2$ \\
\hline $\begin{array}{l}\text { Prunus africana } \\
\text { (Hook.f.) Kalkm }\end{array}$ & Rosaceae & Boundary & $2 * 2$ \\
\hline $\begin{array}{l}\text { Azadirachta indica } \\
\text { A.Juss. }\end{array}$ & Meliaceae & Boundary & $2 * 2$ \\
\hline
\end{tabular}

\subsection{Experimental Design and Management}

Most of home gardens at the study site have low diversity of tree species and they were selected based on willingness to handle the tree planting and management activities, and availability of free land for planting trees. Two separate experiments were conducted in the homegardens. In experiment one, five indigenous and exotic tree species $(C$. africana, L. leucocephala, A. gumifera, M. ferruginea and $S$. sesban) were planted at a spacing of $4 \mathrm{~m} * 4 \mathrm{~m}$ at the backyard of homegardens (Table 1). In experiment two, four indigenous and exotic tree species (A. indica, M. stenopetala, $G$. robusta, and $P$. africanus) were planted at a spacing of 2 $\mathrm{m} * 2 \mathrm{~m}$ at the boundary of homegardens. Totally ten farmers (five farmers for each experiment) were participated on the study. They have provided 10 seedlings, having similar height, of each species. For both experiment, a randomized complete design was employed. Tree species and farmers were considered as a treatment and replication respectively. Training on how to plant, handle and use the trees was given to farmers and development agents. Tending involved manual weeding and protection from domestic animals were carried out by trial farmers.

\subsection{Assessment and Data Analysis}

The trials were assessed for survival, height and collar diameter growth. Heights were measured using either meter tape or graduated stick depending on the height of the trees being assessed. Collar diameters were assessed at the base of the seedlings or saplings using caliper. Survival assessment was based on the original number of trees planted. Growth and survival data from each trial were subjected to analysis of variance and Least Significance Differences (LSD) tests to enable comparisons of tree species.

\section{Results and Discussions}

\subsection{Survival}

Comparisons for species survival under farmers' management at Shomba site showed that there were significant $(\mathrm{P}<0.05)$ differences among the species at $1,2,3$ years of establishment (Table 2). In the first year assessment, the mean survival rates were grouped in to three. Species like $S$. sesban, G. robusta and C. africana categorized in the first group having average survival rate between 80.6 and $88.9 \%$. M. ferruginea, A. gummifera, $P$. africanus and A. indica categorized in the second group having average survival rate between 68.0 and $76.7 \%$ while L. leucocephala and $M$. stenopetala categorized in the third group with average survival rate between 30.8 and 55.4\% respectively. The lack of significant differences in survival rates among some tree species in the same category suggests that their level of adaptation in the homegardens in the area is more or less the same. All study species, expect $S$. sesban and $L$. leucocephala maintained their survival rate for the whole assessment periods. Low survival of L. leucocephala was attributed to the seedlings were eaten by wild animal whereas seedlings of $M$. stenopetala were unable to survive on swampy homegardens. Most of seedlings planted in well drained gardens survived well. This is because $M$. stenopetala grows best in well-drained soils, and it does not grow in waterlogged or swampy soils $[19,20]$.

Table 2. Mean survival of 3 years old multipurpose tree species tested in homegardens at Shomba site of Gimbo district, South West Ethiopia.

\begin{tabular}{lllll}
\hline \multirow{2}{*}{ Niche } & \multirow{2}{*}{ Species } & \multicolumn{3}{l}{ Survival \% } \\
\cline { 3 - 5 } & Year I & Year II & Year III \\
\hline \multirow{3}{*}{ Backyard $^{*}$} & L. . leucocephala & $86.5 \mathrm{a}$ & $86.5 \mathrm{a}$ & $86.5 \mathrm{a}$ \\
& A. gummifera & $72.9 \mathrm{~d}$ & $24.8 \mathrm{~d}$ & $24.8 \mathrm{~d}$ \\
& M. ferruginea & $76.7 \mathrm{~b}$ & $72.9 \mathrm{~b}$ & $72.9 \mathrm{~b}$ \\
& S. sesban & $88.9 \mathrm{a}$ & $88.9 \mathrm{~b}$ & $76.7 \mathrm{~b}$ \\
& A. indica & $68.0 \mathrm{c}$ & $68.0 \mathrm{c}$ & $60.0 \mathrm{a}$ \\
Boundary $^{* *}$ & M. stenopetala & $55.4 \mathrm{c}$ & $55.4 \mathrm{c}$ & $55.4 \mathrm{c}$ \\
& G. robusta & $80.6 \mathrm{a}$ & $80.6 \mathrm{a}$ & $80.6 \mathrm{a}$ \\
& P. africanus & $75.2 \mathrm{~b}$ & $75.2 \mathrm{~b}$ & $75.2 \mathrm{~b}$ \\
\hline
\end{tabular}

Means in columns with the same letters are not significantly different using LSD

* the tree species were planted at the backyard of homegardens ** planted at the boundary of homegardens

\subsection{Height Growth}

Transplanted seedlings of the tree species in the homegardens varied significantly $(\mathrm{P}<0.05)$ in their height gained over the years (Table 3 ). Among tree species planted at the backyard of homegardens, $S$. sesban $(1.70 \mathrm{~m})$ gained the highest mean height significantly during the first year of monitoring and followed by L. leucocephala $(0.85 \mathrm{~m}), A$. gummifera $(0.68 \mathrm{~m})$ and $C$. africana $(0.67 \mathrm{~m})$. M. ferruginea $(0.58 \mathrm{~m})$ had the least mean height growth. The mean height growth for the aforementioned tree species was maintained 
consistently for the second and third year assessment period except $C$.africana $(3.46 \mathrm{~m})$ had gained better mean height significantly than $A$. gummifera $(3.00 \mathrm{~m})$, and $M$. ferruginea $(2.18 \mathrm{~m})$ at the third year of assessment. The result of this study was in line with Tilahun et al [17] who reported better early growth performance of $S$. sesban in Sinana, South eastern Ethiopia. Betre Alemu et al [15] also reported superior performance of $S$. sesban as compared to other indigenous and exotic tree species at Chefe Donsa, central highlands of Ethiopia. This could be attributed to the genetic superiority of the species.

Among tree species planted at the boundary of homegardens, M. stenopetala $(1.36 \mathrm{~m})$ and $G$. robusta $(0.8$ $\mathrm{m})$ were the highest mean height gainers during the first year of experimentation. M. stenopetala is native to southern Ethiopia [21] and the Gofa, Konso, Burji, and Gamo tribes consume its leaves as a vegetable [22, 23]. However, the tree species is not well known in the study area. The present study revealed that the climatic condition of the study area was suitable for growing of $M$. stenopetala species. The species does not have any specific soil requirements, except it does not grow on waterlogged or swampy soils [24]. During the second and third year of monitoring, G. robusta performed significantly $(\mathrm{P}<0.05)$ better than $M$. stenopetala, $P$. africanus and $A$. indica. Tilahun et al [17] reported better early growth performance of $G$. robusta as compared other species like C. cunninghamiana, $C$. equistifolia, $L$. leucocephala and A. decurrrens in Sinana, south eastern Ethiopia. G. robusta is a multi-purpose tree, it is popular for fuel, timber and as a windbreak. It is also used for making high quality furniture and light construction [25]. The golden flowers of species are attractive to bees, making it an important honey plant [24].

Table 3. Mean height and diameter growth of 3 years old multipurpose tree species tested in homegardens at Shomba site of Gimbo district, South West Ethiopia.

\begin{tabular}{|c|c|c|c|c|c|c|c|}
\hline \multirow{2}{*}{ Niche } & \multirow{2}{*}{ Species } & \multicolumn{2}{|l|}{ Year I } & \multicolumn{2}{|l|}{ Year II } & \multicolumn{2}{|c|}{ Year III } \\
\hline & & H (m) & CD (cm) & H (m) & CD (cm) & H (m) & CD (cm) \\
\hline \multirow{5}{*}{ Backyard } & C.africana & $0.67 \mathrm{a}$ & $1.2 \mathrm{~b}$ & $2.80 \mathrm{~b}$ & $6.02 \mathrm{c}$ & $3.46 \mathrm{~b}$ & $7.50 \mathrm{~d}$ \\
\hline & L. leucocephala & $0.85 \mathrm{~b}$ & $1.13 \mathrm{~b}$ & $2.94 \mathrm{~b}$ & $4.46 \mathrm{~b}$ & $3.04 \mathrm{~b}$ & $5.37 \mathrm{c}$ \\
\hline & A. gummifera & $0.68 \mathrm{a}$ & $0.79 \mathrm{a}$ & $1.89 \mathrm{a}$ & $3.33 \mathrm{a}$ & $3.00 \mathrm{~b}$ & $4.10 \mathrm{~b}$ \\
\hline & M. ferruginea & $0.58 \mathrm{a}$ & $0.89 \mathrm{a}$ & $1.89 \mathrm{a}$ & $2.95 \mathrm{a}$ & $2.18 \mathrm{a}$ & $3.26 \mathrm{a}$ \\
\hline & S. sesban & $1.70 \mathrm{c}$ & $2.05 \mathrm{c}$ & $5.04 \mathrm{c}$ & $9.60 \mathrm{~d}$ & $6.26 \mathrm{c}$ & $11.78 \mathrm{e}$ \\
\hline \multirow{3}{*}{ Boundary } & M. stenopetala & $1.36 \mathrm{c}$ & $2.39 \mathrm{c}$ & $2.46 \mathrm{c}$ & $6.51 \mathrm{~d}$ & $3.41 \mathrm{~b}$ & $8.30 \mathrm{~d}$ \\
\hline & G. robusta & $0.80 \mathrm{c}$ & $1.02 \mathrm{~b}$ & $3.03 \mathrm{~d}$ & $4.70 \mathrm{c}$ & $4.16 \mathrm{c}$ & $5.87 \mathrm{c}$ \\
\hline & P. africanus & $0.73 \mathrm{~b}$ & $0.92 \mathrm{~b}$ & $1.83 \mathrm{~b}$ & $2.68 \mathrm{~b}$ & $2.23 \mathrm{a}$ & $3.50 \mathrm{~b}$ \\
\hline
\end{tabular}

Means in columns with the same letters are not significantly different using LSD

H: Height (m); CD: Collar Diameter (cm)

\subsection{Root Collar Diameter}

Diameter of most of the tree species measured in terms of gains in root collar diameter (RCD) was shown in table 3 and similar to gains in their heights. Among species planted at backyard of homesteads at first and second year of experimentation, $S$. sesban had the highest mean RCD significantly $(\mathrm{P}<0.05)$ and followed by $C$. africana and $L$. leucocephala. The minimum $\mathrm{RCD}$ was attained by $M$. ferruginea and A. gummifera. At the third year of assessment, the RCD of tree species ranking followed the order: $S$. sesban $(11.78 \mathrm{~cm})>$ C. africana $(7.50 \mathrm{~cm})>$ L. leucocephala $(5.37$ $\mathrm{cm})>$ A. gummifera $(4.10 \mathrm{~cm})>M$. ferruginea $(3.26 \mathrm{~cm})$. Among species planted boundary of homesteads, $M$. stenopetala and $A$. indica consistently had the highest and lowest mean RCD significantly $(\mathrm{P}<0.05)$ than the other species respectively. At the second and third year of experimentation, M. stenopetala was followed by G. robusta and $P$. africanus. Results of the present study indicated that most of tree species having the greatest root collar diameter were those which grew tallest. Significant positive correlation $(\mathrm{r}=0.72)$ was observed between height growth and root collar diameter development of the tree species. Tilahun et al [17] and Abebe et al [14] reported similar correlation between height and root collar diameter growth of multipurpose tree species.

\section{Conclusions and Recommendations}

Among tree species tested in the homegardens, S. sesban, $C$. africana, $G$. robusta and $P$. africanus are the most promising tree species tested in agroforestry homegardens. Though M. stenopetala showed low survival rate in low drained homegardens, it was very fast growing tree species in the study area. Besides indigenous tree species, A. gummifera and $M$. ferruginea, growing of exotic tree species like $S$. sesban and $G$. robusta in agroforestry homegardens could help farmers to get woody and non-woody forest products from their gardens and hence, reduce the pressure on the natural forest in the area. Generally, studies are recommended to examine the contribution of tested species to soil improvement and crop yield, and identify additional native and exotic species suitable for agroforestry homegardens.

\section{Acknowledgements}

The authors acknowledge Southern Agricultural Research 
Institute and Bonga Agricultural Research Centre for financing the study and facilitating the process. The authors are also grateful to numerous staff of Bonga Agricultural Research Center, in particular, to Abiy G/Micheal, Hailemariam Gizaw (Dr), Dirshaye Milkias, Bedilu G/Kidan, Abrham Engida, Tatek Mekuriya and Yared Taffese for their help in carrying out the experiment.

\section{References}

[1] B. Badege. Deforestation and land degradation in the Ethiopian highlands: a strategy for physical recovery. Northeast African Studies, 2001, vol. 8(1), pp. 7-26.

[2] T. Demel. Deforestation, wood famine, and environmental degradation in Ethiopia's highland Ecosystems: urgent need for action. Northeast African Studies, 2001, vol. 8(1), pp. 5376 .

[3] T. Gobeze, M. Bekele, M. Lemenih and H. Kassa. Participatory forest management and its impacts on livelihoods and forest status: the case of Bonga forest in Ethiopia. International For. Rev., 2009, vol. 11 (3) pp. 346358 .

[4] N. K. R. Nair. An introduction to agroforestry. Kluwer Academic Publisher, Dordrecht, The Netherlands, 1993. pp. 499.

[5] A. Tesfaye. Diversity in homegarden agroforestry systems of Southern Ethiopia, Dissertation, Wageningen University. The Netherlands, 2005.

[6] Y. Getahun, A. Zebene, and Z. Solomon. Wood production and management of woody species in homegardens agroforestry: The case of small holder farmers in Gimbo district, South West Ethiopia. International Journal of Natural Sciences Research, 2014, vol. 2(10), pp. 165-175.

[7] B. Zobel and Jalbert J. Applied Forestry Improvement. John Wiley and Sons, New York, 1984, pp. 505.

[8] J. Evans. Plantation Forestry in the Tropics. Oxford University Press, New York, 1986.

[9] P. Savill, E. Julian, A. Daniel and F. Jan. Plantation silviculture in Europe. Oxford University Press, Oxford, 1996, pp. 312 .

[10] K. Eldridge, J. Davidson, C. Harwood and G. van Wyk. Eucalypt Domestication and Breeding. Clarendon Press. Oxford, 1994, pp. 288.

[11] G. Orlander. Growth of some forest trees in Ethiopia and suggestions for species selection in different climatic zones. Swedish University of Agricultural Sciences, Umea, 1986, pp. 54.

[12] A. Tesfaye. Growth performances of some multipurpose trees and shrubs in the semi arid area of southern Ethiopia. Agrofor. syst., 1994, vol. 26, pp. 237-24.

[13] J. Davidson. Eucalyptus Tree Improvement and Breeding. Ministry of Natural Resources Development and
Environmental Protection, Forestry Research Centre, Addis Ababa, Ethiopia, 1995.

[14] Y. Abebe, B. Diriba and B. Taye. Growth performance of different multipurpose tree and shrub species at Bako,western oromiya. pp 177- 189. In: Proceeding of the fifth Conference of the Ethiopian Society of Soil Science. Adiss Ababa, Ethiopia. 30-31 March 2000, Ethiopian Society of Soil Science, Adiss Ababa, Ethiopia, 2000.

[15] A. Betre, M. Tekalign, Z. Alemayehu, and A. Ebrahim. Promising multipurpose tree species and their response to landform on highland Vertisols at Chefe Donsa, Central highlands of Ethiopia. pp. 145-155. In: Proceeding of the fifth Conference of the Ethiopian Society of Soil Science. Adiss Ababa, Ethiopia. 30-31 March 2000, Ethiopian Society of Soil Science, Adiss Ababa, Ethiopia, 2000.

[16] H. Tesfaye and A. Mohammed. Adaptability and growth performance of short rotation forestry species in Arba Minch, southern Ethiopia. Ethiopian Journal of Natural Resources (EJNR), 2005, vol. 7(1), pp. 83-94.

[17] C. Tilahun, D. Motuma, A. Yifru, and Y. Mengitstu. Screening of multipurpose tree and shrub species for adaptability and growth performance at Sinana, South-Eastern Ethiopia. Ethiopian Journal of Natural Resources (EJNR), 2006, vol. 8(2), pp. 271-279.

[18] CBFED. Cordination Bureau of Finance and Economic Development. Regional Atlas. Southern Nations, Nationalities and People's Regional Sate Bureau of Statistics and Population. E.M press. Hawassa, Ethiopia, 2004.

[19] ICRAF."Moringa stenopetala", Available at: http://www.worldagroforestry.org/Sea/Products /AFDbases/ AF/asp/SpeciesInfo.asp (Accessed 8 September 2006).

[20] N. Steinmüller, K. Sonder, and J. Kroschel. "Fodder tree research with Moringa stenopetala a daily leafy vegetable of Konso people, Ethiopia" 2002, Available at: http://www.tropentag.de /2002/ proceedings/node62.html (Accessed 29 August 2006).

[21] T. Demel (Ed.). Edible Wild Plants in Ethiopia, Addis Ababa University Press, Addis Ababa, 2010, pp. 260-262.

[22] C. Abuye, K. Urga, H. Knapp, D. Selmar, A. M. Omwega, and J. K. Imungi. "A compositional study of Moringa stenopetala leaves", East African Medical Journal, 2003, vol. 80 (5), pp. 247-252.

[23] E. Demeulenaere. "Moringa stenopetala, a subsistence resource in the Konso district", paper presented to the scientific meeting on development potential for Moringa products, Dar es Salaam, Tanzania, 29 October-2 November, 2001 Dissertation, Wageningen University, The Netherlands.

[24] C. Orwa, A. Mutua, R. Kindt, R. Jamnadass, S. Anthony. Agroforestry Data base: a tree reference and selection guide version 4.0, 2009 Available at: http://www.world agroforestry.org/sites/treedbs/treedatabases.asp (Accessed 19 August 2015).

[25] F. Reinhard, and A. Admasu. Honeybee Flora of Ethiopia. Benedict Press, Munsterschwarzach, Germany, 1994, pp. 510. 